\title{
Bcl-2-Like Protein 12
}

National Cancer Institute

\section{Source}

National Cancer Institute. BCl-2-Like Protein 12. NCI Thesaurus. Code C114745.

$\mathrm{Bcl}$-2-like protein 12 (334 aa, $\sim 37 \mathrm{kDa}$ ) is encoded by the human BCL2L12 gene. This protein is involved in the inhibition of apoptosis. 